\title{
Comparison of Success Management Effect of Therapy Use of Generic Drugs and Branded Drugs in Typhoid Fever Patients in Installation of Inpatients
}

\author{
Gemy Nastity Handayany, Trimaya Cahya Mulat, Irawaty Irawaty, Anwar Mallongi* \\ Department of Environmental Health, Faculty of Public Health, Hasanuddin University, Makassar, Indonesia
}

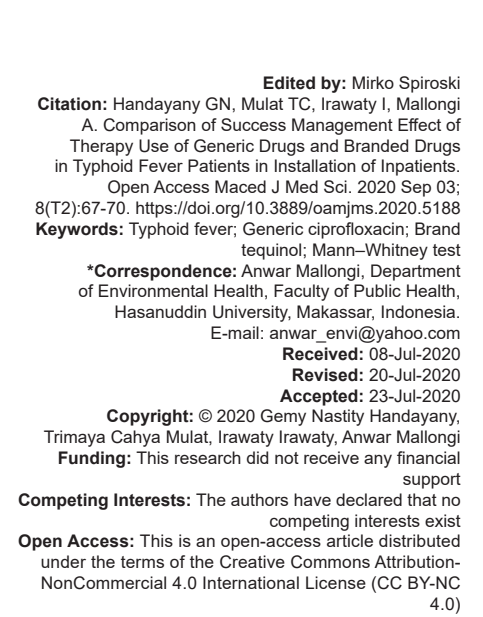

\begin{abstract}
AIM: This research aim to know the comparison of efficacy of the effect therapy uses generic ciprofloxacin and branded drug tequinol from patient of typhoid fever

METHODS: The research method has the character of the descriptive observational with the technique intake of sample is consecutive sampling/quota sampling. Subject research was conducted on 67 sample fulfilling criterion of inclusion and exclusion diagnosed by typhoid fever at period January-March 2018.

RESULTS: Thirty-four patients use the generic ciprofloxacin and 33 patients use the brand tequinol. Time of fever degradation for patient using brand tequinol range from 1 to 3 day and for patient using generic ciprofloxacin 3-7 day. CONCLUSION: After tested to use the Mann-Whitney test, there is difference having a meaning of hospitalization of to lodge briefer and free from fever quicker at brand tequinol than generic ciprofloxacin at patient of typhoid fever in RSUD Haji Makassar $(p<0.05)$
\end{abstract}

\section{Introduction}

Based on observations made in December 2017 at the Haji District Hospital in South Sulawesi Province, it is one of the public hospitals that offers modern, complete, and quality Islamic health services for children, individuals, families, and employees of all age groups so that the hospital this is often used by the community as a place of treatment, especially for patients suffering from typhoid fever. Haji Regional Hospital of South Sulawesi Province is one of the hospitals that handle the most typhoid fever by ranking first in 2016 in South Sulawesi based on the disease index data in the Haji Regional Hospital of South Sulawesi Province.

From the results of observations of data on the use of drugs for typhoid fever in Haji Hospital South Sulawesi Province, the use of generic drugs during January 2018-March 2018 was $62.25 \%$ and branded drugs were $37.77 \%$. Based on observations, the cure for typhoid fever using the ciprofloxacin generic drug with a drug uses rate of $17.65 \%$ and tequinol brand of $16.66 \%$ of a total of 204 cases.
Typhoid fever is a systemic infection caused by Salmonella enterica serovar Typhi (Salmonella typhi) [1]. Therapy that can be done to treat diseases caused by bacterial infections such as S. typhi is by giving the right antibiotics. Based on antibiotic use data at the Makassar Hajj District General Hospital, the antibiotic that is often prescribed for $S$. typhi bacterial infections that cause typhoid fever is the drug ciprofloxacin [2].

The choice of antibiotic for $S$. typhi infection depends on the severity of the infection. The primary choice of infection pharmacotherapy in S. typhi bacteria according to Pharmacotherapy A Pathophysiologic Approach Edition 10 of 2017 is ciprofloxacin, levofloxacin, ceftriaxone, and cefotaxime [3].

Previous research by Kesselheim et al., [4] in the journal Clinical Equivalence of Generic and Brandname Drugs used in Cardiovascular Disease believes that generic drugs and branded drugs have almost the same bioequivalent and equally worthy drug choices. For all patients by Karan et al. [5], whereas according to Tange et al. [6] that generic drugs and branded drugs have a large difference in the level of impurity (impurity) 
of about $3 \%$ in the formulation so that it affects the bioavailability of the drug.

Based on observations at Makassar Haji Hospital, doctors often prescribe generic drugs to patients but not a few also prescribe branded drugs. This is because doctors are usually faced with the constraints of generic drug stock vacancies so that doctors eventually turn to trademarked drugs or patent medicines. As a result, the use of branded drugs is increasingly being prescribed by doctors to patients especially if the patient comes for treatment a second time it will be given a similar prescription for the same case before.

\section{Materials and Methods}

\section{Data collection}

A total of 67 cases of a total of 204 cases that met the inclusion and exclusion criteria diagnosed with typhoid fever in the January 2018-March 2018 period were then sampled to compare the therapeutic results of the use of 34 patients using the generic drug ciprofloxacin and 33 patients using brand tequinol.

\section{Data analysis}

Data were then analyzed with the help of descriptive statistical methods using the SPSS application version 24. Patient demographic profiles for each area of therapy were expressed in terms of gender (number and percentage), and age class (number and percentage), type of drug used, outcome of patient treatment outcomes, and duration of therapy seen from the disappearance of fever.

The criteria for patients in this study are as follows:

\section{Inclusion Criteria}

The following criteria were included in the study:
a. Adult patients (15-60 years) with a diagnosis of typhoid fever who have been hospitalized during January-2018
b. Patients treated with positive Widal test results
c. Patients receiving ciprofloxacin generic antibiotic treatment
d. Patients receiving antibiotic treatment with brand name tequinol
e. Patients who do not have concomitant diseases
f. Patients who are otherwise allowed to go home/recover by a doctor.

\section{Exclusion criteria}

The following criteria were excluded from the study:

a. Typhoid fever patients with concomitant diseases

b. Patient did not complete therapy/forced discharge

c. Patients with incomplete and unclear medical records.

\section{Research parameters}

a. Duration of patient's fever decreased days (fever free time)

b. The patient's length of stay.

\section{Results}

Based on Table 1 can be seen ciprofloxacin generic frequency data 34 or $50.7 \%$ and cumulative percent of $50.7 \%$. Meanwhile, the frequency of brand tequinol is 33 or $49.3 \%$.

Table 1: Distribution of inpatient antibiotic use for typhoid fever in Makassar Haji Hospital

\begin{tabular}{lll}
\hline Antibiotic & Frequency & $(\%)$ \\
\hline GC & 34 & 50.7 \\
BT & 33 & 49.3 \\
Total & 67 & 100.0 \\
\hline
\end{tabular}

The length of stay of typhoid fever patients while in Makassar Hajj General Hospital with the longest stay for 8 days with a total of 1 patient $(1.5 \%)$ and the most frequent length of stay, namely, during 4 days with a total of 26 patients (38.8\%) (Table 2).

There were 17 patients who used the tequinol brand who experienced a decrease in fever within 3 days and 11 patients using the generic ciprofloxacin. The day of fever reduction which has the most frequency in patients using Ciprofloxacin is 4 days with a total of 16 patients (Table 3 ).

Based on the Mann-Whitney statistical test, the value obtained is 85,000 and the significance value is 0.000 or $(p<0.05)$ by Sopiyudin [7], because $p<0.05$ can be concluded that "there is a significant difference between the generic use of ciprofloxacin and the tequinol brand against length of stay of the patient" (Table 4).

\section{Discussion}

Based on the results of the study, the distribution of the number of typhoid fever patients by sex is male (37.3\%) and female (62.7\%). Typhoid fever can occur in all sexes in both women and men. This is in accordance with the report of the Ministry of Health of the Republic of Indonesia Ministry of Health [8] that typhoid fever is 
Table 2: Distribution of length of stay of patients with typhoid fever in Makassar Haji Hospital

\begin{tabular}{llll}
\hline Day & Frequency & $(\%)$ & Cumulative (\%) \\
\hline 2 & 3 & 4.5 & 4.5 \\
3 & 11 & 16.4 & 20.9 \\
4 & 26 & 38.8 & 59.7 \\
5 & 19 & 28.4 & 88.1 \\
6 & 5 & 7.5 & 95.5 \\
7 & 2 & 3.0 & 98.5 \\
8 & 1 & 1.5 & 100.0 \\
Total & 67 & 100.0 & \\
\hline
\end{tabular}

found more in women than men. Symptoms of typhoid fever usually appear 1-3 weeks after exposure and may be mild or severe. Symptoms based on research conducted most commonly experienced by typhoid fever patients are fever/heat as much as $100 \%$ or a total of 67 patients. Symptoms in the form of fever are the most prominent symptom. Fever will be followed by other non-typical symptoms such as diarrhea, constipation, anorexia, nausea, and vomiting [9].

Table 3: Disturbances for the length of day of fever reduction in typhoid fever patients based on the type of antibiotic

\begin{tabular}{llllllll}
\hline \multicolumn{7}{c}{ Count } \\
\hline Kind antibiotic & \multicolumn{7}{c}{ Day of fever reduction (day)' } \\
\cline { 2 - 7 } & 1 & 2 & 3 & 4 & 5 & 7 & \\
\hline GC & 0 & 0 & 11 & 16 & 6 & 1 & 34 \\
BT & 1 & 15 & 17 & 0 & 0 & 0 & 33 \\
Total patient & 1 & 15 & 28 & 16 & 6 & 1 & 67 \\
\hline
\end{tabular}

Patients who were said to have typhoid fever were patients who had Widal values $>1 / 160->1 / 640$ for agglutinin $\mathrm{O}$ and $\mathrm{H}$ with single or combined diagnostic criteria by Jawetz et al. [10], Widal test is a laboratory examination to detect the presence or absence of antibodies in patients with antigens $O$ (from the body of germs), $\mathrm{H}$ antigens (germ flagella), and Vi antigens germ capsules [11]. In this study, the antibiotics used were generic ciprofloxacin and brand tequinol. Both types of antibiotics have the same active ingredient, namely, ciprofloxacin. Ciprofloxacin drug is one of the fluoroquinolone antibiotics. According to Bueno and Stull [12], fluoroquinolone is an antibiotic that has a broad spectrum and has strong activity in inhibiting Gram-positive and Gram-negative bacteria.

Table 4: Statistical results of Mann-Whitney description of length of stay and length of fever reduction in typhoid fever patients at Makassar Haji Hospital in the period January-March 2018

\begin{tabular}{lll}
\hline Parameter & LRI & LPD \\
\hline Mann-Whitney U & 85.000 & 142.500 \\
Wilcoxon W & 646.000 & 703.500 \\
Z & -6.244 & -5.529 \\
Asymp. Sig. (2-tailed) & 0.000 & 0.000 \\
\hline
\end{tabular}

The fastest average length of treatment was patients who received therapy with brand tequinol than patients who received the ciprofloxacin generic and after being tested using the Mann-Whitney statistical test obtained a significance value of 0.000 or $(p<0.05)$ because $p<0.05$, Sopiyudin [7] can be concluded that "there is a significant difference between the generic use of ciprofloxacin and the tequinol brand on the length of stay of patients."

The therapeutic response seen from the heatfree time is one of the parameters of the success of the treatment of typhoid fever; if the body temperature drops it means the treatment is successful, whereas if the temperature remains high there may be other infections, complications, or multidrug resistant S. typhi. The antibiotic that gives the fastest fever-free time is the tequinol brand compared to the ciprofloxacin generic. The duration of fever reduction for patients using the tequinol brand ranges from 1 to 3 days and for patients using ciprofloxacin generic ranges 3-7 days. The length of time the patient's fever is reduced which is also influenced by the symptoms the patient has. After being tested using the Mann-Whitney test, there was a significant difference in fever-free time between generic ciprofloxacin and tequinol brand in typhoid fever patients in Makassar Haji Hospital ( $p<0.05)$.

The Spearman correlation value between length of stay with the type of antibiotic (generic ciprofloxacin and brand tequinol) was -0.769 and the Spearman correlation value between the duration of fever reduction with the type of antibiotic (generic ciprofloxacin and brand tequinol) was -0.681 indicating that the direction of the negative correlation with the strength of the correlation was strong $(0.769$; $0.681>0.5)$ [13].

\section{Conclusion}

The therapeutic effect of using brand tequinol gives shorter stay than ciprofloxacin. The therapeutic effect of using brand tequinol gives a time to reduce fever faster than generic ciprofloxacin.

\section{References}

1. Nelwan $\mathrm{RH}$. Tata laksana terkini demam tifoid. Continuing Med Educ. 2012;39(4):247-50.

2. Kemenkes RI. Pedoman Pelayanan Kefarmasian Untuk Terap Antibiotik. Jakarta: Departement Kesehatan RI; 2011.

3. Dipiro JT, Wells BG, Dipiro C, Wells BG, Posey LM. Pharmacotheray a Pathophysiologic Approach. $10^{\text {th }}$ ed. London: McGrew Hill; 2017. p. 4668.

4. Kesselheim AS, Misono AS, Lee JL, Stedman MR, Brookhart MA, Choudhry NK, et al. Clinical equivalence of generic and brand-name drugs used in cardiovascular disease. JAMA. 2008;300(21):2514-26. https://doi.org/10.1001/jama.2008.758 PMid: 19050195

5. Karan C, Tapas M. Arnav A, Thomasc J, Mondald T. A global comparison between brand-name and generic drugs. Indian $\mathrm{J}$ Pharm Pract. 2014;7(3):23.

6. Tange M, Yoshida M, Nakai Y, Uchida T. Comparison between original and generic version of ceftriaxon sodium preparation for injection: Compability with calcium-containing product. Chem Pharm Bull (Tokyo). 2012;60(4):429-34. https://doi.org/10.1248/ cpb.60.429 
PMid:22466725

7. Sopiyudin D. Statistik Untuk Kedokteran dan Kesehatan: Deskriptif, Bivariat, dan Multivariat, Dilengkapi Aplikasi Menggunakan SPSS. Jakarta: Salemba Medika; 2012.

8. Kemenkes RI. Pedoman Pengendalian Demam Tifoid. Jakarta: Pengendalian; 2006.

9. Widoyono. Penyakit Tropis. Jakarta: Erlangga; 2012.

10. Jawetz E, Melnik L, Adelberg EA. Medical Microbiology. Jakarta: Penerbit EGC; 2012
11. Bakr WM, El Attar LA, Ashour MS, El Toukhy AM. The dilemma of widal test which brand to use? A study of four different widal brands: A cross sectional comparative study. Ann Clin Microb Antimicrob. 2011;10(1):8. https://doi.org/10.1186/1476-0711-10-7 PMid:21303511

12. Bueno SC, Stull TL. Antibacterial agents in pediaatrics. Infect Dis Clin North Am. 2009;23(4):865-80. PMid:19909888

13. Setyoawati M. Petunjuk SPSS (Statistical Product and Service Solutions). Semarang: Universitas Dian Nuswantoro; 2017. 